\section{A guide to statistical techniques in psychology and education}

\section{GORDON RAE \\ New University of Ulster, Coleraine BT52 1SA, Northern Ireland}

This interactive program is intended to help students decide which statistical technique is best suited for analyzing a particular set of research data. It takes the form of a routine within which the student responds to a series of questions about his or her problem. At the end of the routine, the student is told which statistical technique(s) might be appropriate and what assumptions are involved in using the technique(s). References to popular statistical textbooks and readily available journal articles are also provided for the student who wishes computational details. It is presumed that the user of the program is conversant with fundamental principles of experimental design and with the basic notions of measurement theory (see Appendix).

The statistical tests cited in the program divide into three broad categories. The first deals with measures of relationship between two variables. The user is asked to indicate whether the data in each set are a true dichotomy, a false dichotomy, nominal data or limited category ordinal data, ordinal data from a multiple category variable, or interval or ratio data. Eleven different measures of correlation or association are suggested, covering all possible combinations of these five different types of measurement.

The second category includes tests that may be used when the researcher wishes to compare the observations or scores yielded by two or more samples. The computer selects the most appropriate test, based on such factors as the number of samples involved, the nature of these samples (independent or related) and the population from which they were drawn, and the level of measurement employed (nominal, ordinal, interval, or ratio). Assistance is also given in choosing an appropriate post hoc multiple-comparison test.

The last category includes a number of parametric and nonparametric tests that may be used when the researcher wishes to determine whether a single sample could have come from some specified population.

Computer and Language. The program is written in BASIC and was prepared and tested on an ICL1903A computer. It can be readily modified to include additional references and tests if sufficient core storage is available.

Limitations. The program does not deal with multivariate analysis (i.e., the simultaneous analysis of more than one independent variable and/or more than one dependent variable). ${ }^{1}$

Flow Chart. The flow chart for the program was partly based on guidelines produced by Glass and
Stanley (1970), Hopkins and Chadbourn (1967), and Siegel (1956) for correlational methods, parametric post hoc multiple-comparison tests, and nonparametric tests, respectively.

Availability. A listing of the program and sample runs may be obtained without charge from Gordon Rae, Education Centre, New University of Ulster, Coleraine BT52 1SA, Northern Ireland.

\section{REFERENCES}

Glass, G. V., \& Stanlfy, J. C. Statistical methods in psychology and education. Englewood Cliffs, N. J: Prentice-Hall, 1970.

Hopkins, K. D., \& Chadbounn, R. A. A scheme for proper utilization of multiple comparisons in research and a case study. American Educational Research Journal, 1967, 4, 407-412.

SiEgkl., S. Nonparametric statistics for the behavioral sciences. New York: McCiraw-Hill. 1956.

\section{NOTE}

1. This definition of multivariate analysis includes factorial analysis of variance. However, techniques for analyzing data from treatments by subjects (or repeated measures) designs are cited in the program.

\section{APPENDIX}

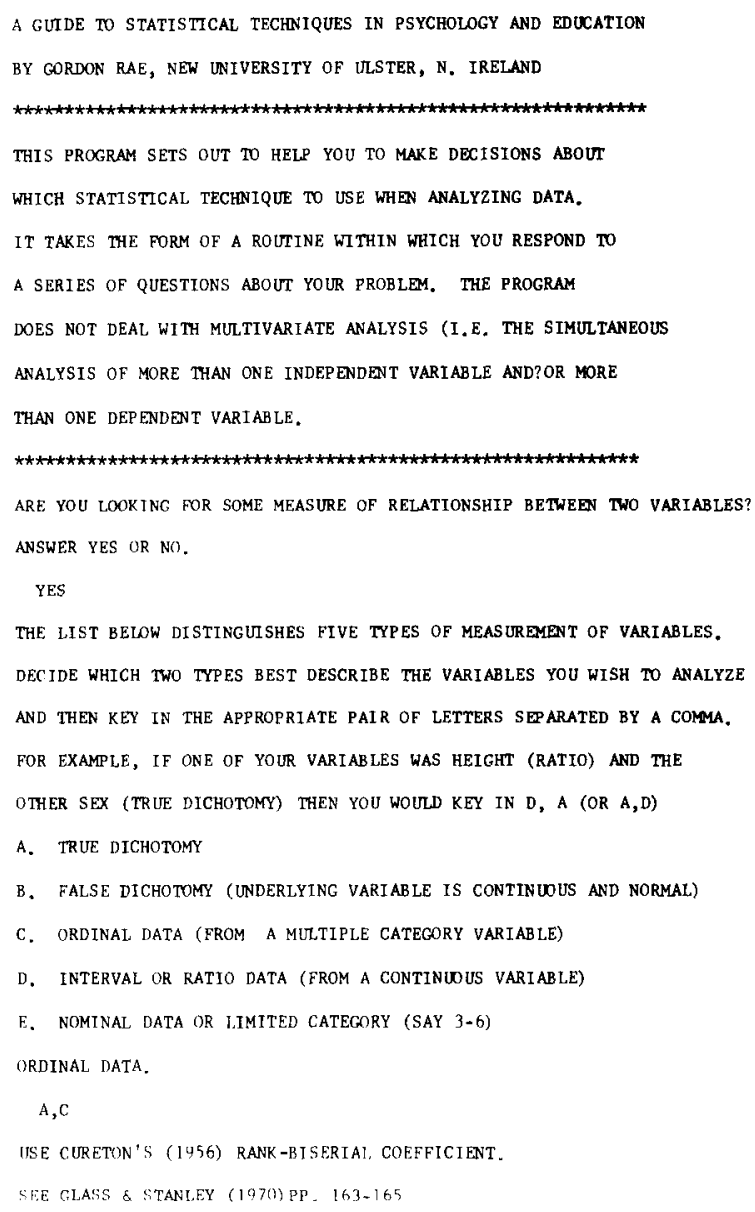




\section{RAE}

DO YOU WISH A LIST OF REFERENCES?

ANSWER YES OR NO.

no

HAVE YOU ANOTHER PROBLEM?

ANSWER YES OR NO.

YES

ARE YOU LOOKING FOR SOME MEASURE OR RELATIONSHIP BETWEEN

TWO VARIABLES?

ANSWER YES OR NO.

No

DO YOU WISH TO COMPARE SCORES FROM TWO OR MORE GROUPS?

ANSWER YES OR NO.

YES

IS THE DATA INTERVAL?

ANSWER YES OR NO.

No

IS THE DATA ORDINAL?

ANSWER YES OR NO.

YES

DO YOU ONLY HAVE TWO SAMPLES?

ANSWER YES OR NO.

No

DO YOU HAVE MORE THAN TWO SAMPLES?

ANSWER YES OR NO.

YES

ARE YOUR SAMPLES INDEPENDENT?

ANSWER YES OR NO.

YES

USE THE KRUSKAL-WALLIS ONE-WAY ANALYSIS OF VARIANCE OR EXTENSION

OF THE MEDIAN TEST, SEE SIEGEL (1956) PP. 184-193 AND

PP. 179-184, RESPECTT VELY.

DO YOU NOW WISH TO CONDUCT MULTIPLE COMPARISONS?

ANSWER YES OR NO.

YES

SEE PAPER BY WIKE (1974).
DO YOU WISH A LIST OF REFERENCES?

ANSWER YES OR NO,

YES

BURROUGHS, G, E, R, DESIGN AND ANALYSIS IN EDUCATIONAL RESEARCH, UNIV. OF BIRMINGHAM, ENGLAND, 2ND. ED. 1975.

BRLNING, J. L. \& KINTZ, B. L. COMPUTATIONAL HANDBOOK OF STATISTICS, SCOTT FORESMAN \& CO. ILLINOIS, 1968.

DUNN, O.J. MULTIPLE COMPARISONS AMONG MEANS.

J. AMER, Statistical ASSOC, VoL, 56, 1961, PP. 52-64. FERGUSON, G.A, STATISTICAL ANALYSIS IN PSYCHOLOGY AND EDUCATION. MCGRAW-HILL, N.Y., 2ND.ED., 1966.

GLASS, G.v. \& STANLEY, J.C. STATISTICAL METHODS IN EDUCATION AND PSYCHOLOGY. PRENTICE-HALL, 1970 .

HAYS, W.L. STATISTICS FOR THE SOCIAL SCIENCES, HOLT, RINEHART \& WINSTON, 2ND. ED., 1977.

LINDQUIST, E. F. DESIGN AND ANALYSIS OF EXPERIMENTS IN PSYCHOLOGY AND EDUCATION. HOUGHTON-MIFFLIN, 1953.

MCCALL, R.B. \& APPEIBAUM, M.I. BIAS IN THE ANALYSIS OF REPEATED MEASURES DESIGNS: SOME ALTERNATIVE APPROACHES, CHILD DEV, VOL, 44 , 1973, PP. 401-415.

SIEGEL, S. NONPARAMETRIC STATISTICS FOR THE BEHAVIORAL SCIENCES.

MCGRAW-HILL, N.Y. 1956.

WIKE, E. L. SOME NONPARAMETRIC MULTIPLE COMPARISON TESTS. PERCEPTUAL \& MOTOR SKILLS, VOL. 38, 1974, PP. 1055-1058.

WINER, B.J. STATSTTICAL PRINCIPLES IN EXPERTMENTAL DESIGN.

MCGRAW-HILL, N.Y. 2ND.ED., 1971.

HAVE YOU ANOTHER PROBLEM?

ANSWER YES OR NO.

No

TRY AGAIN.

ANSWER YES OR NO.

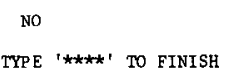

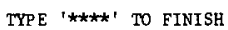

(Accepted for publication March 30, 1980.) 